\title{
Knowledge Construction In Ecological Sustainability Of The Women
}

\author{
Raudlatul Jannah $^{1 *}$, Baiq Lily Handayani ${ }^{2}$, Hary Yuswadi ${ }^{3}$, \\ Nurul Hidayat ${ }^{4}$ \\ ${ }^{1,2,3,4}$ Department of Sociology, Faculty of Social Science and Politic, Universitas Jember \\ Jalan Kalimantan 37 Jember, Indonesia \\ Email: raudlatuljannah.fisip@unej.ac.id \\ Email: baqi.fisip@unej.ac.id \\ Email: hary_yuswadi.fisip@unej.ac.id \\ Email: nurul_hidayat.fisip@unej.ac.id
}

\begin{abstract}
The background of this research about environmental problems, such as loss of soil fertility, depletion of groundwater, river pollution, waste management, seem to be a phenomenon that is happening right now. Human dependence on nature is increasingly critical, but it is not balanced with an awareness of environmental preservation. The purpose of this research is to find out and describe the construction of women's ecological sustainability in Jember. This construction includes water management, power management, transportation use, and waste management. This study uses a qualitative method with interviews as a data collection technique. The informants of this study were selected from six villages in Jember, namely Karangrejo, Antirogo, Tegalgede, Kalisat, Sumbersari, and TegalBesar villages. This study uses a purposive method, especially housewives whose activities relate to these indicators. The results showed that women had limited knowledge construction about ecological sustainability. This construction develops based on daily experience and individual knowledge of the ecological preservation models around them. Therefore, household waste is often found scattered in the ecosystem.
\end{abstract}

Keywords: women, ecologicalsustainability, water, energy and wastemanagement 
Jannah, Handayani, Yuswadi, Hidayat:

Knowledge Construction In Ecological

Sustainability Of The Women In Region

\begin{abstract}
Abstrak
Latar belakang penelitian ini tentang masalah lingkungan, seperti hilangnya kesuburan tanah, penipisan air tanah, pencemaran sungai, pengelolaan limbah, tampaknya menjadi fenomena yang saat ini sedang terjadi. Ketergantungan manusia pada alam semakin kritis, tetapi tidak diimbangi dengan kesadaran pelestarian lingkungan. Tujuan dari penelitian ini adalah untuk mengetahui dan mendeskripsikan konstruksi keberlanjutan ekologis perempuan di Jember. Konstruksi ini meliputi pengelolaan air, manajemen daya, penggunaan transportasi, dan pengelolaan limbah. Penelitian ini menggunakan metode kualitatif dengan wawancara sebagai teknik pengumpulan data. Informan penelitian ini dipilih dari enam desa di Jember, yaitu desa Karangrejo, Antirogo, Tegalgede, Kalisat, Sumbersari, dan Tegal Besar. Penelitian ini menggunakan metode purposive, terutama ibu rumah tangga yang kegiatannya berkaitan dengan indikatorindikator ini. Hasil penelitian menunjukkan bahwa perempuan memiliki konstruksi pengetahuan yang terbatas tentang keberlanjutan ekologis. Konstruksi ini berkembang berdasarkan pengalaman sehari-hari dan pengetahuan individu tentang model pelestarian ekologi di sekitarnya. Karena itu, limbah rumah tangga sering ditemukan tersebar di ekosistem.
\end{abstract}

Kata kunci: perempuan, kelestarian ekologis, air, energi dan pengelolaan limbah 


\section{INTRODUCTION}

As a developing country, Indonesia must deal with environmental damage which has been increasingly massive (Giessen et al. 2016). The data from the environment office show the rates of forest destructions reached out 1.8 million hectares each year and approximately $70 \%$ of the coral reefs were damaged because of the waste and water pollution by the industrial waste, the massive productive land conversion, and the waste problems that have not been resolved. These phenomena also happened in Jember Regency. One out of five important issues faced by Jember Regency was that there had not been a good and healthy environment yet. It can be shown from the indicator of the decline of forest area, the conversion productive land into housing complex (FKB praised the improvement of the environment quality in Regent Faida period, beritajatim/20juli2017), the vanishing springs in the upstream of the DAS Bedadung river basin (Ikhwanuddin 2010), also the waste management problem that citizens had not been aware of (the result of the discussion with the chief of Waste Management Office of Jember regency).

According to Arne Naess, the recent environmental crisis could only be solved by changing people's mindset and their behavior towards the environment fundamentally and radically. The new mindset involves not only in individual behavior but also in the culture as a whole. The false mindset in the way looking and putting oneself in nature produces behavior patterns that are exploitative towards nature. Consequently, the improvement that should be done must foster people's mindset towards nature, environment, and sustainability as well as the human future. The role of women dealing with the environment is fundamentally crucial. At least, women are verily close to nature (Shiva 1997). For example, their role in managing the household waste on their own farms and their role of women leadership in public sectors producing policies related to environmental management.

This study showed a research finding of construction of ecological sustainability on the women in Jember regency that could be the basis for formulating efforts to revitalize the women's role towards the environment in Jember regency (B Asilsoy \& D Oktay 2016). Overall, this study was in line with the development of sociological knowledge related to the women issue, 
Jannah, Handayani, Yuswadi, Hidayat:

Knowledge Construction In Ecological

Sustainability of The Women In Region

environmental sustainability, and the ability to formulate the solutions and innovations for social welfare (Toka 2008).

The concept of ecological sustainability is also closely related to human attitudes in preserving biological environments (B Agarwal 2000). The attitude of preserving the environment is hugely influenced by knowledge construction as well. In the study conducted by group research called WEST (West, Ecology, and Sustainability) from the Sociology Department of Jember University in 2018 about the construction of ecological sustainability on the women in Jember Regency, the researchers used some indicators to see the construction of ecological sustainability. Some indicators were water management, energy management, the use of transportation, and waste management (Sanjeeb Kakoty 2018).

This study was conducted on the women living in Jember Regency. The women were carefully chosen based on the consideration that their daily activities as the household managers are close to nature. For example, they use water ever since they wake up in which they use for washing the dishes, cooking, doing the laundry, cleaning the house, and throwing out the trash. Also, generally, household activities such as turning off or using the electricity likewise cooking rice and watching television are mostly carried out by women as well (Sanjeeb Kakoty 2018).

The close affiliation between women and ecology is not only because of their roles as the household managers but also because of the historical and cultural reasons (Agarwal 2000). These reasons explain why women have a higher concern for nature. One example of the women movement to show their concern for the environment was Chipkomovement in India. Shiva (1988) writes that women are more concerned about environmental sustainability in the forest than men who tend to take wood for building materials and local factories (Shiva 1997). However, the research findings of the construction of ecological sustainability among the women in Jember Regency quite varied. As they were explained further in the discussion section. 


\section{METHODS}

This study used a qualitative method with a constructivist approach. The researchers carried out in-depth analysis and interpretation of various women's activities (Berger, Peter L, and Luckman, 1990) including household activities such as washing, cooking, and throwing the trash. The areas of the research were in Jember Regency, specifically in six different villages which were, Karangrejo, Antirogo, Tegalgede, Kalisat, Tegalbesar, and Sumbersari. The technique used to determine the research informants was a purposive technique with particular criteria. The data collection method was carried out by observing the daily life of the women, especially their affiliation with the environment. Moreover, several spot areas such as rivers, housing conditions, toilets, septic tanks, garbage dumps, and residents' wells became distinctive concerns (Wring 2006).

The in-depth interview was done at the informant houses while they were doing their activities. The documentation was carried out in the form of photos of the activity. Data validity was tested by using a triangulation technique or crosscheck data (Jhon W Creswell 2014). The obtained data then were further categorized based on air management, energy management, transportation usage, and waste management. After that, the data reduction was applied, and temporary hypotheses were drawn. If the data were regarded as insufficient, the data collection was reconducted until the data were considered to be saturated.

Humans inevitably take the largest part of the natural environment or earth compared to other living creatures. This is certainly driven by a human biological ability that is special and different from animals. Humans have not only intelligence but also instinct to survive and to develop their ability to conquer the earth. Further Berger and Luckmann mentions that the process of being humans takes place in a reciprocal relationship with the human and natural environment. It means that specific cultures and societies are linked through the intercession of influential people who take care of them to shape their human identity (Berg and Oscarsson 2015).

In their idea of society as objective reality, Berger and Luckman hugely emphasize on social environment aspect that can form an individual. Selfcharacter is not only about individual self-configuration but also about comprehensive psychological development which reflects on the cultures where 
the individuals were raised. In its later journey, human extinction depends greatly on order, direction, and stability. On the other hand, this social order is the result of continuous human production (Burak 2018).

The origin of institutionalizations begins with human behaviors done repeatedly that shape patterns which later are reproduced. In the development of these reproduced patterns, they become a mechanism used by institutions in society. Then institutions in the society implicate historicity and control (Setiawati et al. 2013).

Specifically, understanding the behavior of Indonesian people especially in their knowledge constructions of ecological sustainability is largely determined by objective and subjective realities of the community (Kamh, Khalifa, and ElBahrawy 2016). In this case, the role of knowledge lies in the dialectics between the individual and community also between personal identity and social structure in the community. The knowledge construction of ecological sustainability is a social construction as well. The process of this social construction occurs in the interaction of women in their community and in their culture. The better understanding of environmental sustainability the women have, the better the social environment contributes to the women's knowledge (Mollborn and Everett 2015). Environmental sustainability refers to a concept that emphasizes the ability of the environment to maintain its resources stably both for the biodiversity and for the function of supporting the ecosystem and social environment.

The concept of ecological sustainability has become an important keyword in national development especially these days where the environmental damage occurs massively and spreads both in urban and rural areas. In the context of the behavior of the people in Jember, there are six dimensions of people behavior towards nature which as follows; (1) energy-saving, (2) water conservation, (3) waste management, (4) public participation, (5) sustainable transportation, and (6) green consumption (Asilsoy 2012;B Asilsoy \& D Oktay 2016).

Ecological sustainability refers to the biosphere capacity to meet the needs of the present generation without ignoring the needs of future generations (Vinay 2018). Also, the concept of ecological sustainability is closely related to the behavior of taking advantage of nature wisely both for the short term and for the long term period. Meanwhile, the discussion about environment covers not only 
about biological environment but also about the social environment (Vinay 2018). In other words, a sociological approach is highly needed to overcome the challenges of the current environmental problems.

The concern about ecological sustainability has continually developed especially over the last few decades. It can be seen in some studies which relatively link ecological sustainability with economic growth, culture, and the human future looks at the ecological sustainability in local and global dimensions while Goodland prefers to focus more on the ecological sustainability in the context of time and economic implication and global concerns (Robert Goodland 1995). Even though this concept is connected to some ambiguities, Jabareen (2004) adds that there needs an emphasis on the wise use of natural resources in the relationship between human and economic development (Yosef Jabareen 2004). Kakoty (2018) wisely sees that the wisdom of traditional society becomes significant knowledge along with the eco-friendly technology so as to produce a sustainable economic perspective (Sanjeeb Kakoty 2018).

\section{RESULTS AND DISCUSSIONS}

Water management based on the result of the research which had been done, especially in the indicators of water management, the social construct was based on the behavior in managing the water by the women. It seemed to refer to women's social class (Stark, Mäs, and Flache 2015). All this time, water management was based on the water facility owned by each household. Based on the water facility had bay the households in Jember Regency, the researchers found several patterns that were related to the behavior in managing the water based on the owned water facility.

The first way was the women took a turn in collecting the water from their neighbor's well by using a bucket. The water, then, was brought to each of their houses manually. As soon as they got at home, the water which they brought was collected in a bucket, for both cooking and taking a bath. This condition left them no choice but to save more water and use it in a very well planned, for example, to wash the vegetables, dishes, or rice, they collected the residual water which had been used. Then, the residual water was used to water the plants and yards. Meanwhile, for MCK needs (taking a bath, urinating, and doing the laundry), they 
Jannah, Handayani, Yuswadi, Hidayat:

Knowledge Construction In Ecological

Sustainability of The Women In Region

did in the river, spring, and the area around the sharing well. In this first way, the distance of the nearest spring (well) which they used was less than $1 \mathrm{~km}$.

Based on this everyday experience, the women constructed water as a muchneeded resource in their life (Setiawati et al. 2013). The challenge of walking to the spring as well as carrying the water to their houses gave its own meaning. For them, the water became a rare commodity which made the women needed to use the water as prudent as possible. The existence of sharing well or spring had also constructed the society's objective reality about the orderliness, water distribution, and patience in queuing the water. Also, this reality enabled the formation of society's control mechanism in which the women supervised each other in the distribution of water, especially during the dry season.

The second way was the women collected the water from a family-owned well using a water pump. Generally, this was done by the society who lived in a densely populated area and did not have any land to build their own wells. Some families, especially those whose houses were close to each other and had a relationship as one big family, joined the pipes to that well and streamed the water directly to each of their houses. The pipes were joined not only to the bathroom but also to the kitchen for cooking. By using this way, the women usually used the flowing water to wash the rice, vegetables, and dishes. Some of the families even had a washing machine. During the dry season, the women would save up the water since the water discharge decreased drastically. Even, in some of them, there was behavior in supervising the water collection (Steinberg 2007). Every woman who utilized the water from that well must collect the water in an equal portion as the others.

The third way was the women had their own wells, but they did not either use any water pump or have any faucet in their houses. Thus, they still needed to collect the water from the well and used it to fill in the water tub in the bathroom. In this condition, they only needed to build a simple bathroom around the well and collected the water by pulling up the bucket using a pulley. The water, then, was collected in the water tub and used. Even though those women had enough land to build their own wells, they did not have enough money to build a bathroom inside the house. Hence, whenever they needed to defecate, they would do it in the river or soak-sok. 
The fourth way, for the women who lived in a housing complex, they usually had a house that had already had MCK in it and the clean water was supplied from the well or PDAM (a Government company taking care of the water supply). Generally, for the women who lived in that area, they could use the water quite freely. One of the examples was they were able to always use the flowing water to do the laundry, wash the vegetables and cook. By using this way, the women usually used the flowing water for their every need. For the women who had enough water facility, they usually did not collect the residual water but immediately dumped it through the drains or ditches.

The fact which could not be denied was there was an increasing demand for water which was in line with the increasing number of development and population. Unfortunately, the increasing demand for water was not followed by maintaining the water sources. Based on the research data obtained, although the women really needed the water, they, mostly, did not have the knowledge to maintain the water. This was clearly seen from their behavior, which still utilized the water as a commodity. When they were capable of purchasing that commodity freely due to their good financial condition, they would use the water as much as possible. However, if they found it difficult to access the water, they would use it more carefully and wisely.

In Karangrejo and Sukorejo Village, the people used the water from the river to do MCK, while they used the nearest brook from their houses as a septic tank, where they directly disposed of the waste from their bathroom. Before having a bathroom, they still used a river for their everyday needs. Yet, after they had already had a bathroom, they felt that the river was no longer necessary for their needs, while actually river was once the center of the civilization (Nurlidiawati 2014). The decision to make the river a septic tank was based on the cost savings considerations. According to the informants, it was not necessary to build a septic tank as it was believed that it would cost a lot of money. Due to this reason, it was better for them to dispose of it to the river or brook and, moreover, the position of the river or brook was right behind their houses. Nevertheless, some of the informants complained that during the rainy season, the overflowing water from the rivers went up through the pipes into their bathrooms. This was quite troublesome, but it seemed like they had already gotten used to it. 
Jannah, Handayani, Yuswadi, Hidayat:

Knowledge Construction In Ecological

Sustainability Of The Women In Region

During the dry season, the people in Tegalgede, Antirogo, and Karangrejo had a habit to do torap. Torap is an activity to raise the water from the sources of water like river, spring, or ditch to be watered or flowed around the well in order to make it seep into the dirt and fill in the well. This was done because the people's wells were dry. There were several kinds of Torap:

1. Streaming the water through the ditch in front of the people's houses for 12 hours or a night. This was done by several Tegalgede people who lacked water from the well. Then, they collected several amounts of money, around Rp $10.000-15.000$, to pay an officer who took care of the water to stream the water from Dam 3 to the ditch in front of their houses. After getting flowed by the water a whole night, the water in the wells which were located around the ditch would be filled in and, therefore, could be used for their necessity that needed water for a week. The next week, the people would ask the officer again to stream their ditch.

2. Rising the water from the river using a water pump, then it was watered near the well all day long or stopped if the thought that it had been enough.

The process of streaming the well using Torap method was quite effective to solve the problem about the lack of water of the well. Moreover, though the water was taken from a dirty river, the ground would filter and clean the quality of the water which enabled it to be consumed by the people.

This water crisis phenomenon, unfortunately, did not come with the ability of the women to maintain the sustainability of water sources. This fact was indicated from the findings where, generally, the informants did not have any knowledge about how to maintain the groundwater (Goldblum and Wong 2000). This was seen from their unawareness about the importance of making an infiltration well. Most of the informants did not have any infiltration well. Even, they did not know the benefits of the infiltration well. Besides, most of them did not understand what bio pure infiltration holes were as well as their benefits. Even, though they understood the importance of perennials to store the water inside the ground, the women still did not feel that it was necessary to plant them around their houses to store the groundwater. Especially for the people who lived in the housing complex, they did not plant the perennials because they did not 
have enough land. However, for those who had enough land to plant the perennials, they still preferred to pave their yards.

Energy managementterms of energy management, the lower up to middle classes society had a habit to save more energy compared to those in the upperclass society, especially for the lighting needs. It was because not only they merely had access to the low electrical capacity, but also they had another consideration on the household operational financing. The economical consideration became the main reason for the energy saver. In terms of the utilization of the sunlight to lighten the room, the researchers found that some of the poor families could not utilize the sunlight to help brighten their rooms, so they used lamps nonstop for 24 hours.

All the woman informants in Jember Regency did not use any alternative energy for their everyday needs, either for cooking, heating the water, or lighting. This was due to their lack of both awareness about the alternative energy and initiative from the people to look for any local alternative energy which could be used. Of course, the selection of the alternative energy was not conducted all of sudden. This was based on the reality of objective society in which there was barely any externalization process which made it possible for them to get information about alternative energy which they could use. Also, there was no institutionalization process about alternative energy.

Generally, the society had used energy-saving lamps. There were only a few women who still used the light bulbs. Even if there was any, it was a poor family that usually used the light bulb with low wattage to brighten their room nonstop for 24 hours. For the middle up to upper-class families, they usually had one or two LED television and $\mathrm{AC}$ in each house. In using the $\mathrm{AC}$, the informants usually set their temperature below 20 degrees Celsius. Besides, in terms of using the TV, the need to watch the TV was quite high in the middle-class women who lived in a rural area. The number of hours they spent at home and their role in taking care of their children made it necessary for them to watch TV at least 12 hours a day. This was done to drive away their boredom and to prevent their children play too far from home.

This was in line with what Wilk found when he tried to connect the culture and energy use. He found that culture influenced the behavior in using the energy so much. The energy use, which tended to be extravagant, was also supported by 
Jannah, Handayani, Yuswadi, Hidayat:

Knowledge Construction In Ecological

Sustainability of The Women In Region

the cultural understanding, especially the problem of over-consumption in the modern society. This could also be found in reality, in which the upper-class women tended to use the energy more wastefully (Wilk, Richard R. 2002).

The women's behavior in managing the energy showed that the knowledge of energy management was still not much(Franzia, Piliang, and Saidi 2015). The energy consumption behavior was still determined by the informants' economic ability; the more ability the women had in using the energy, the higher the energy consumption in their household was. Some of the lower class informants said that if they did not save their energy consumption, for example, the energy used for lamps or TV, their electricity bills would become expensive and increase their monthly operational household cost as well. Based on the informants' answers, there was no one who connected their behavior to the proactive attitude of energy saving. This could be understood since in the society, the comprehension about sustainable energy management behavior did not become institutionalized knowledge, so there was not any internalizing process of the values of environmental awareness (Ivan and Iov 2013).

For transportation use, generally the main activities of the informants were working and taking care of the household. Taking care of the household could be in terms of dropping off and picking up their children from school as well as doing grocery shopping. At this current time, most of the women in Jember Regency rode automatic motorcycles when doing an activity outside. Besides riding a motorcycle, the informants also traveled by public transportation called angkot to do grocery shopping. To travel in further distance, they chose to travel by train, public bus, or personal car.

The finding of this research mentioned that middle and upper-class family, on average, had more than one motorcycle in each house. Even, the ownership of these motorcycles could be based on the number of adults in that house. One of the examples was for family A which had two children who were still in the university, they would have had two motorcycles. Moreover, for the upper-class families, they would rather choose Pertamax when filling their motorcycles' tank as they considered it would be better for the internal combustion of their motorcycles. Meanwhile, for the middle and lower-class families, they usually preferred Pertalite for their motorcycle. For the lower class families, even though 
they preferred Premium to Pertalite for their motorcycles, they had no other choice than to choose Pertalite as some of the gas stations (SPBU) no longer sold premium.

The need for motorcycles became quite high, mainly due to the distance of the house which was far from the access to public transportations. For the middle and lower-class families, they, mostly, bought used motorcycles at affordable prices. Also, they usually did not do the machine maintenance regularly. Besides, the informants said that they did not check the wind pressure of their motorcycles regularly either.

For the middle and lower class informants, the use of motorcycles was for their everyday needs instead of a lifestyle. One of the examples was a family which had to buy a motorcycle for their kid who studied in a Senior High School outside their village in order to make him/her easier to travel to school. For the informants, traveling to school or other places that were needed as a part of their daily routine by motorcycle was considered more efficient compared to traveling by angkot or other public transportations. This was based on the consideration that they just needed to fill up the gasoline for only Rp 25.000 in a week, to be able to do their daily activity easily and without having to wait for the public transportation on the road. Also, they did the fuel savings by making sure the destination route before leaving so that they would not use up the fuel by going through the routes that were not supposed to be traveled. Besides, they would share one same vehicle if they had the same destination route.

Most of the informants did not put any environmental reason into consideration when using the motorized vehicles. Mostly, their main consideration was practicality and cost savings. For the informants, traveling by motorcycle was more practical than by angkot as they did not have to wait for angkot to come. Also, the use of motorcycle was considered to be more efficient since they only needed to spend about Rp 8.000 to fill out the gasoline, then they could ride the motorcycles to several destinations at once instead of spending $\mathrm{Rp}$ 5.000 for angkot which took them to one destination only.

Waste management of the household is generally handled by women, especially mothers.In the middle and lower class society, sorting the wet waste (organic) and plastic waste (inorganic) were based on economic value. If the stuff has economic value, it will be stored in a specific place. After some were 
Jannah, Handayani, Yuswadi, Hidayat:

Knowledge Construction In Ecological

Sustainability of The Women In Region

collected, they will be exchanged with new plastic stuff such as pail or pan. This practice was called as urup-urup.

There were several treatmentsfor wet waste. First, if the household owned cattle, the organic waste of leftover food and vegetable chunk will be fed to their cattle. Second, for organic waste like animal's manure, they used it as organic fertilizer for their plants in the garden. Third, wet waste was collected in plastic then thrown to the river or sok-sok. The last, organic and inorganic waste were put together and burnt in their own yard.

Some women who lived in the village, they were reluctant to pay garbage collector to collect their waste. The problem aroused when the women lived in a narrow yard or they did not even have one to put or burn the garbage. They eventually disposed of the garbage by throwing them into the river, in the sewer, or on the roadside. In This kind of situation, women are suspected to play a very big role in environmental pollution, for example by throwing disposable diapers into the river (Rofiah 2017, Gysma 2014).

In the middle and upper class especially the ones who lived in a housing complex, they had a mechanism in disposing of waste by doing it collectively which was hiring a garbage man. Every month, they pay a clean and social fee for every 10 households (dama/dasawisma). The payment is collected at the PKK, dama social gathering, or RT meeting. This way, in most cases they did not have any problem of garbage piling up and their environment appear clean.

Based on the research finding, the informants mostly sorted the garbage, especially plastic waste to be sold to urup-urup or waste bank. Selling plastic garbage to urup-urup is done by women who lived in the village. Urupurupmanwould routinely go around every village to buy the garbage collected by the housewives. For Waste Bank, the researcher only found it in Taman Gading Housing.Waste Bank "SahabatIbu" was founded in 2016 by PKK women group of RT 06 RW 40 Taman Gading housing complex. It was initiated by Mira Evyanti Christina, the wife of community leader RT 06. This waste bank has 40 women as a member. It generates 100 to 4000 thousand each month. All of the income was collected and shared among the members every year when it was close to iedfitri. The waste savings of every member wasvarious between 5 thousand up to 300 thousand rupiah. Throughout the year, the financial 
management of the waste bank is in collaboration with the grocery cooperative. The women who became the member of a waste bank usually possessedthe knowledge and environmental awareness Waste sorting was done routinely and facilitated by waste bank group. This neighborhood also provided education on waste management Waste bank Sahabat Ibu also works together with environmental services. The women in this neighborhood, mostly, knows to reuse, reducing and recycling waste.

Meanwhile, Some Women who lived in a housing complex generally did not sort their wastebecause they perceived that they did not have a waste problem. These women thought that, with the existence of a garbage collector, there would nothave any problem with waste, and it was proven by the clean environment. Furthermore, for working women, they did not think they have time or was lazy to sort the waste. The other reasons were limited space to keep the sorted waste, and there was no strict regulation which make them did not feel the need to sort the waste. The last reason found by the researcher was women mostly did not have the knowledge on why waste should be sorted. However, the women generally who lived in the village or the city, especially the middle and upper classes carried out reusing by giving away the stuff that they do not need anymore to the other family or donating them when disaster happen. This practice generally applied to clothes, shoes, book or even bag that was still feasible to use.

The knowledge of women about environmental sustainability in the perspective of social construction.Women play an important role in nature, and their daily lives are tightly connected to water, energy source, and waste management. Other than the user of the environment, women also have the potential to damage the environment. In managing water, women with the limited water supply which had to use community well and carried water using a pail to the house tended to be frugal of water. While the ones who used PDAM water and had tap water inside their house were prone to use water excessively. Women's knowledge on water conservation through infiltration well and bio pure hole was limited. Only a few informants had that knowledge and have infiltration well at home. 
Jannah, Handayani, Yuswadi, Hidayat:

Knowledge Construction In Ecological

Sustainability of The Women In Region

Figure 1

The social construction of ecological sustainability among women

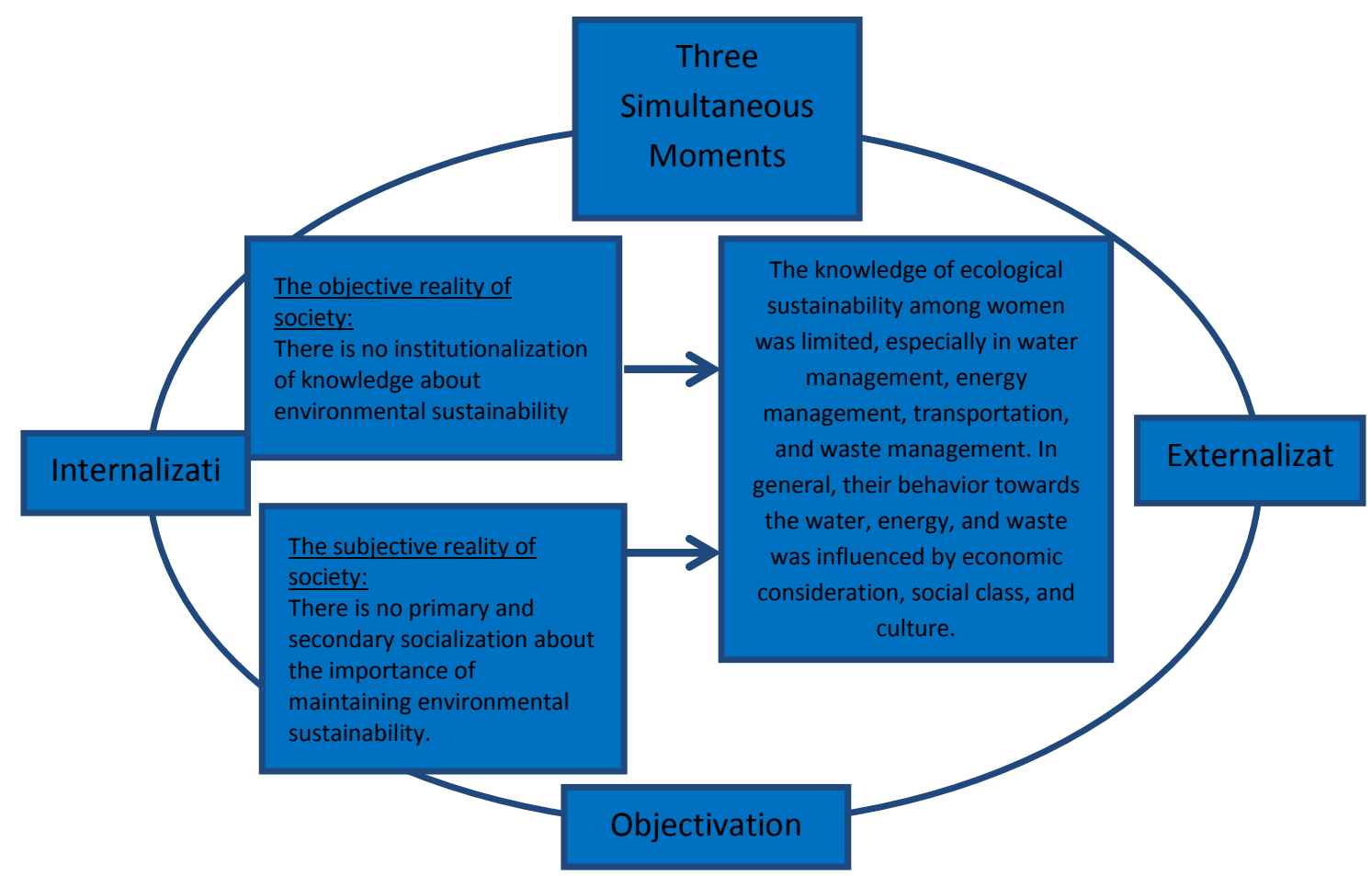

(Note: Social construction of ecological sustainability among women (Vinay

2018).

In the matter of energy management, the lower class women tendedto save more energy. Their economic situation became the main reason to limit the use of electricity. While in middle and upper classes, women mostly used more electric appliances other than $\mathrm{AC}$, television, lamp, more than one $\mathrm{TV}$, washing machine, and blender. The conductof using electricity excessivelywas because they could afford the monthly bill.Keeping the TV on even though noone is watching is a wasteful of electricity and mostly done by the women both in the village and in the city.

In the case of waste management, women sorted their garbage based on economic value, which the collected garbage then are sold to urup-urupman or waste bank.The women who lived in housing complex with waste bank developed awareness to have better waste management in the form of reduce, reuse, and recycle. While for women who did not get education about waste, they only sorted the garbage based on economic consideration. For the woman who lived in the village area and did not have garbage collectors, they normally disposed of their 
own waste which mostly led to littering and ended up polluting the surrounding ecosystem.

Building the construction in Ecological Sustainabilitywas as important as upholding ecological justice. The less knowledge is possessed by the community about environmental sustainability and overconsumption behavior, the more human's well-being is at stake. Touche (Sanjeeb Kakoty 2018) even stressed that environmental justice is closely related to ecological sustainability. Environmental sustainability is a global supporting system for human life (Robert Goodland 1995). Other than achieving environmental sustainability, stability and reducing environmental burden will also be achieved as stated by Singh which are global warming, sea and river pollution, acid rain, air and land pollution (Singh 2009). Even though the indicators of understanding environmental sustainability were based on people in the city especially women if the overconsumption behavior kept being practiced, the natural resources will be quickly depleted, besides, economic growth brings the people to endless consumption culture.

The rapid growth of global industries is deemed responsible for environmental damage (Kumar, Dives, Goyal, Praveen Rahman, Zillur, Kumar 2011). This also happened in Indonesia since some forest was turned into factories which made some springs disappear and led to drought in some places, even in Jember. Besides forest fire and animal extinction, referring to Berger (2018), no institutionalization in the society and primary and secondary socialization in spreading the knowledge of environmental sustainability made the idea about conserving the environment not constructed socially (Peter L Berger \& Luckman Thomas 2018). Therefore, more institutionalization is needed not only to overcome the environmental degradation problem but also to develop a further vision to build a sustainable environment (Walker 2008).

\section{CONCLUSION}

From this study, It could be concluded that the knowledge construction of Ecological sustainability among women in Jember was limited.The reasons were lack of education for the woman and no institutionalization that were responsible to educate and control the behavior of the community toward the environment The missing organizations of environmental conservation in the community made them never undergo knowledge accumulation process about environmental 
Jannah, Handayani, Yuswadi, Hidayat:

Knowledge Construction In Ecological

Sustainability Of The Women In Region

sustainability when they were in externalization phase. In the next phase where women became the entity in the community, they never or rarely get primary socialization about how to address water, transportation, energy, and waste management so that in the objectivation phase, they were not able to construct the knowledge on how to conserve the environment. Even though some of the knowledge was taught at school if there is no institutionalization in the community, the social construct on ecological sustainability would be scarce among women.

\section{REFERENCES}

Asilsoy, B. 2012. "A Survey Study On Environmental Consciousness in Fagamusta." Procedia-Social and Behavioural Sciences 35:675-81.

B Agarwal. 2000. "Conceptualising Environmental Collective Action: Way Gender Matters." Cambrigde Jurnal of Economic.

B Asilsoy \& D Oktay. 2016. "Environmental Attitudes as Predictors of Ecological Citizenship: Findings from a Survey in Famagusta, North Cyprus." Open House International (Special Issue on Transformations of Architecture and Urbanism of Cities in the Global South, Eds: A. Salama \& D. Grierson) 41(2):47-55.

Berg, Linda and Henrik Oscarsson. 2015. The Swedish General Election 2014.

Burak, Begüm. 2018. "Media Discourse, Ideology and Print Media in Turkey." Electronic Journal of New Media 2(2):53-62.

Franzia, Elda, Yasraf Amir Piliang, and Acep Iwan Saidi. 2015. "Manifestation of Minangkabau Cultural Identity through Public Engagement in Virtual Community." Procedia - Social and Behavioral Sciences 184:56-62.

Giessen, Lukas, Sarah Burns, Muhammad Alif K. Sahide, and Agung Wibowo. 2016. "From Governance to Government: The Strengthened Role of State Bureaucracies in Forest and Agricultural Certification." Policy and Society 35(1):71-89. Retrieved (http://dx.doi.org/10.1016/j.polsoc.2016.02.001).

Goldblum, Charles and Tai-Chee Wong. 2000. "Growth, Crisis and Spatial Change: A Study of Haphazard Urbanisation in Jakarta, Indonesia." Land Use Policy 17(1):29-37.

Gysma, Pristi. 2014. "Rasionalitas Tindakan Masyarakat Lingkungan Krajan Barat Dalam Membuang Sampah Di Sungai Bedadung.” Universitas Jember. 
Ikhwanuddin, Mawardi. 2010. "Kerusakan Daerah Aliran Sungai Dan Penurunan Daya Dukung Sumber Daya Di Pulau Jawa Serta Upaya Penanganannya." Hidrosfir Indonesia 5 No.2:1-11.

Ivan, Adrian Liviu and Claudia Anamaria Iov. 2013. "Minority Issues at the End of the 20th Century and the Beginning of the 21th Century. Case Study: The Hungarian Minority from Romania." Procedia - Social and Behavioral Sciences 92:426-31.

Jhon W Creswell. 2014. Penelitian Kualitatif Dan Desain Riset. Memilih Diantara Lima Pendekatan. Jogjakarta: Pustaka Pelajar.

Kamh, Yasmin Z., Marwa A. Khalifa, and Aly N. El-Bahrawy. 2016. "Comparative Study of Community Resilience in Mega Coastal Cities Threatened by Sea Level Rise: The Case of Alexandria and Jakarta." Procedia - Social and Behavioral Sciences 216:503-17.

Kumar, Dives, Goyal, Praveen Rahman, Zillur, Kumar, Ishwar. 2011. "Sustainable Consumption in India: Challenges and Opportunities." Int. J. Manag. Bus. Stud 1(3):28-31.

Mollborn, Stefanie and Bethany Everett. 2015. "Understanding the Educational Attainment of Sexual Minority Women and Men." Research in Social Stratification and Mobility 41:40-55.

Nurlidiawati. 2014. "Sungai Sebagai Wadah Awal Munculnya Peradaban Umat Manusia." Rihlah 1 No. 2.

Peter L Berger \& Luckman Thomas. 2018. Tafsir Sosial Atas Kenyataan: Risalah Tentang Sosiologi Pengetahuan. Jakarta: LP3ES.

Robert Goodland. 1995. "The Concept of Environmental Sustainability." Аnnu. Rev.Ecol. Syst.

Rofiah. 2017. "Konstruksi Pengetahuan Dalam Perilaku Membuang Popok Sekali Pakai." Universitas Jember.

Sanjeeb Kakoty. 2018. "Ecology, Sustainability and Traditional Wisdom." Journal of Cleaner Production 172:3215-24.

Setiawati, Endang, Suprihanto Notodarmojo, Prayatni Soewondo, Agus Jatnika Effendi, and Bambang Widjanarko Otok. 2013. "Infrastructure Development Strategy for Sustainable Wastewater System by Using SEM Method (Case Study Setiabudi and Tebet Districts, South Jakarta)." Procedia Environmental Sciences 17:685-92.

Shiva. 1997. Bebas Dari Pembangunan. Perempuan, Ekologi, Dan Perjuangan Hidup Di India. jakarta: Yayasan Obar. 
Singh, Narendra. 2009. "Exploring Socially Responsible Behaviour of Indian Consumers: An Empirical Investigation.” Soc. Respo.

Stark, Tobias H., Michael Mäs, and Andreas Flache. 2015. "Liking and Disliking Minority-Group Classmates: Explaining the Mixed Findings for the Influence of Ethnic Classroom Composition on Interethnic Attitudes." Social Science Research 50:164-76.

Steinberg, Florian. 2007. "Jakarta: Environmental Problems and Sustainability." Habitat International 31(3):354-65.

Toka, Gabor. 2008. "Citizen Information, Election Outcomes and Good Governance.” Electoral Studies 27(1):31-44.

Vinay, Ramachandra and Bharath Setturu1 and S. 2018. "Ecological Sustainability of Riverine Ecosystems in Central Western Ghats." Biodiversity 25-42.

Walker, David. 2008. "Sustainability: Environmental Management, Transparency and Competitive Advantage." J.Retail Leis. Prop.

Wilk, Richard R., Energy. 2002. Science, Policy, and the Pursuit of Sustainability, Chapter Culture and Energy Consumption. Island Press.

Wring, Dominic. 2006. "Focus Group Follies? Qualitative Research and British Labour Party Strategy.” Journal of Political Marketing 5(4):71-97.

Yosef Jabareen. 2004. "A Knowledge Map for Describing Variegated and Conflict Domains of Sustainable Development." J. Environ. Plan. Manag 47(4):623-24. 